\title{
What Factors Influence Knowledge Sharing in Organizations? A Social Dilemma Perspective of Social Media Communication
}

\author{
Razmerita, Liana; Kirchner, Kathrin; Nielsen, Pia
}

Document Version

Accepted author manuscript

Published in:

Journal of Knowledge Management

DOI:

10.1108/JKM-03-2016-0112

Publication date:

2016

License

Unspecified

Citation for published version (APA):

Razmerita, L., Kirchner, K., \& Nielsen, P. (2016). What Factors Influence Knowledge Sharing in Organizations?

A Social Dilemma Perspective of Social Media Communication. Journal of Knowledge Management, 20(6), 1225-1246. https://doi.org/10.1108/JKM-03-2016-0112

Link to publication in CBS Research Portal

\section{General rights}

Copyright and moral rights for the publications made accessible in the public portal are retained by the authors and/or other copyright owners and it is a condition of accessing publications that users recognise and abide by the legal requirements associated with these rights.

Take down policy

If you believe that this document breaches copyright please contact us (research.lib@cbs.dk) providing details, and we will remove access to the work immediately and investigate your claim. 


\section{What Factors Influence Knowledge Sharing in Organizations?: A Social Dilemma Perspective of Social Media Communication}

\section{Liana Razmerita, Kathrin Kirchner, and Pia Nielsen}

Journal article (Post print version)

Cite: What Factors Influence Knowledge Sharing in Organizations? : A Social Dilemma Perspective of Social Media Communication. / Razmerita, Liana; Kirchner, Kathrin; Nielsen, Pia. In: Journal of Knowledge Management, Vol. २०, No. ६, २०१८.

DOI: http://dx.doi.org/10.1108/JKM-03-2016-0112

Uploaded to Research@CBS: September 2016 


\title{
What factors influence knowledge sharing in organizations? A social dilemma perspective of social media communication
}

\begin{abstract}
Purpose: Enterprise social media platforms provide new ways of sharing knowledge and communicating within organizations to benefit from the social capital and valuable knowledge that employees have. Drawing on social dilemma and self-determination theory, the aim of the study is to understand what factors drive employees' participation and what factors hamper their participation in enterprise social media.
\end{abstract}

Methodology: Based on a literature review, a unified research model is derived integrating demographic, individual, organizational and technological factors that influence the motivation of employees to share knowledge. The model is tested using statistical methods on a sample of 114 respondents in Denmark. Qualitative data is used to elaborate and explain quantitative results' findings.

Practical implications: The proposed knowledge sharing framework helps to understand what factors impact engagement on social media. Furthermore the article suggests different types of interventions to overcome the social dilemma of knowledge sharing.

Findings: Our findings pinpoint towards the general drivers and barriers to knowledge sharing within organizations. The significant drivers are: enjoy helping others, monetary rewards, management support, change of knowledge sharing behavior and recognition. The significant identified barriers to knowledge sharing are: change of behavior, lack of trust and lack of time.

Originality: The study contributes to an understanding of factors leading to the success or failure of enterprise social media drawing on self-determination and social dilemma theory.

Keywords: Knowledge sharing, motivation, social dilemma, communication technologies, enterprise social media, engagement.

\section{Introduction}

Knowledge sharing is the process by which employees mutually exchange their tacit and explicit knowledge (Nonaka 2007) in order to create new knowledge. Tacit knowledge resides in the minds of the employees and consists of the "know-how" and skills that individuals have acquired on the basis of personal experience. Explicit knowledge is knowledge that has been written down in manuals or 
guides in order to be shared or communicated to other employees in the organization, who will then also possess this knowledge without having to have the same experience (Newell et al. 2009). "Explicit knowledge sharing requires less effort of an employee to share than tacit knowledge" (Hau et al. 2013). According to Von Krogh et al. (2012), social practices do not only evolve and refine employees' tacit and explicit knowledge. Under certain conditions, such as a history of interaction, their members also pursue higher collective standards of excellence related to their work. Knowledge sharing is intertwined with other knowledge processes including knowledge flow, transfer, learning, distributed collaboration and knowledge creation (Foss et al. 2010, Fayard and Metiu 2014). "Knowledge sharing involves a set of behaviors that aid the exchange of acquired knowledge" (Chow and Chan 2008).

Knowledge sharing is considered to be an important process of social interaction in organizations (Lin 2007, Van den Hooff et al. 2012, Ardichvili et al. 2003) and occurs at individual, group or organizational levels. At the individual and group level, knowledge sharing comprises both knowledge 'donation' and knowledge 'collection' (Lin 2007, Van den Hooff et al. 2012). Knowledge donation involves the employees' motivation to actively communicate with colleagues, as well as consult with colleagues to learn from them (i.e. knowledge collection). At the organizational level, knowledge sharing may be defined as capturing, organizing, reusing, and transferring the experiencebased knowledge which resides within the organization and making that knowledge available to all employees (Lin 2007).

"Knowledge sharing is designed to transform individual into organizational knowledge" (Foss et al. 2010). Knowledge sharing involves leveraging both personal and collective knowledge, and the synergetic articulation of personal into collective knowledge may be facilitated by the adoption of social media platforms (Razmerita et al. 2014). Within this study, social media platforms or enterprise social media refers to organizational usage of technological platforms such as Yammer, Chatter, Podio that facilitate internal communication, collaboration and knowledge sharing.

Enterprise social media are: „web-based platforms that allow workers to (1) communicate messages with specific coworkers or broadcast messages to everyone in the organization; (2) explicitly indicate or implicitly reveal particular coworkers as communication partners; (3) post, edit, and sort text and files linked to themselves or others; and (4) view the messages, connections, text, and files communicated, posted, edited and sorted by anyone else in the organization at any time of their choosing" (Leonardi et al. 2013).

Social media facilitates management and externalization of both personal and organizational knowledge. Externalization of knowledge can take place through multimodal interactions, through videos, pictures, blogs, wikis, answering questions or ongoing online conversations (Razmerita et al. 2014). 
Using social media, employees may engage strategically in self-presentation and have more control over what is perceived because they can take more time to improve their message through written communication. Knowledge sharing through social media offers the opportunity of communal presentation of individual knowledge and also a strategic self-presentation (Leonardi and Treem 2012). Social media facilitates a "shift from online knowledge sharing to continuous online communal knowledge conversations" (Majchrzak et al. 2013). For example, employees can engage in ongoing conversation through online activity streams of various social platforms.

The literature has identified factors that affect the employees' knowledge sharing behavior (King and Marks 2008, Wasko and Faraj 2005, A. Cabrera and E. F. Cabrera 2002). However, only few recent empirical studies exist on which factors affect employees' knowledge sharing behavior covering both social media and traditional means of communication (face to face communication, email). By understanding knowledge sharing behavior and the factors that influence knowledge sharing behaviors using enterprise social media, the aim of this article is to contribute to a better understanding of how knowledge workers can be motivated to share knowledge using social platforms for work-related purposes.

This study draws on self-determination theory (Deci and Ryan 2000) and social dilemma theory (Dawes 1980, Kollock 1998) combined with empirical findings using both quantitative and qualitative data. The aim of this study is to identify the factors under which employees change their choice from a non-participative, "free rider" position to cooperative strategy in which they share knowledge. Selfdetermination theory is concerned with the factors that stimulate or inhibit the desire to engage in a certain behavior and thus help to get insights in how to overcome the knowledge sharing dilemma. The empirical data was collected using a questionnaire distributed to several Danish organizations and through semi-structured interviews. Interviews were conducted within the four organizations that provided the majority of respondents for the survey.

Previous research called for the need for additional studies on motivations for knowledge sharing in different countries (Hung et al. 2011), empirical studies on knowledge sharing as a social dilemma situation (Cabrera and Cabrera 2002) and organizational antecedents of knowledge sharing behaviors (Foss et al. 2010).

The following research question is posed: Which factors affect employees' knowledge sharing behavior within organizations? The study has led to a research framework consisting of significant factors that influence knowledge sharing behavior of employees and social media communication. The research model helps understanding how to motivate employees to share knowledge with social media-emphasizing both drivers and barriers towards adoption of social media at work. 


\section{Theoretical framework and research model}

\subsection{A social dilemma perspective on knowledge sharing}

A social dilemma is defined as a situation in which "individual rationality leads to collective irrationality" (Kollock 1998, Dawes 1980). In other words, individuals attempt to maximize their selfinterests and pay-offs which makes them inclined not to contribute and can consequently lead to collective damage. From a knowledge sharing perspective a social dilemma can be seen as a situation where organizational interests conflict with the employees' individual interests.

"Sharing personal insights with one's co-workers may carry costs for some individuals which may yield to a co-operation dilemma similar to a public good dilemma" (Cabrera and Cabrera 2002).

According to Kollock (1998), a public good is a resource from which all may benefit, regardless of whether they have provided the good or not. According to Cabrera and Cabrera (2005), organizational knowledge can be considered a public good whose availability does not diminish with use. Organizations have an interest in making knowledge available to all employees in order to improve their work performance; but from an employee's point of view it is a rational choice to hoard knowledge in order to save time, conserve power and thereby remain valuable for the organization and reduce the risk of getting fired (Kimmerle et al. 2008, Cabrera and Cabrera 2002, Casimir et al. 2012, Gammelgaard 2004). The employees who do not contribute are "defecting" and free-ride the contribution of others are termed free-riders. It is a rational choice to free-ride from an individual viewpoint, but if all chose to free-ride, no knowledge would be shared (Kollock 1998).

From a social dilemma perspective an employee has two choices: the cooperation strategy ( e.g. the employee is willing to share knowledge or is willing to contribute to public goods repository) or defection strategy when "the production of the joint good is doomed to failure" (e.g. the employee decides to free ride or the joint good is expected to be produced by other colleagues) (Wilkesmann et al. 2009).

By integrating social dilemma theory, this study investigates how to overcome "social dilemma" situations in knowledge sharing, drawing on self-determination theory, in an organizational context. Cabrera and Cabrera (2002) suggest several ways to overcome knowledge sharing dilemma by restructuring the payoff function, by increasing the efficacy of contributing, and increasing group identity as well as personal responsibility. Following a social cooperation strategy most employees are willing to share knowledge or are willing to change their behavior towards adoption of knowledge sharing practices, even if there is a cost, provided the majority of employees contribute. Following a "defecting strategy", employees would not cooperate on sharing or contributing their knowledge to a public good leading to a "deficient equilibrium". The dilemma for employees is 
stronger the higher the costs are for knowledge sharing. Examples of such costs are the cognitive effort it takes to share and edit information and the time it takes away from work that creates real business benefits. Furthermore, some employees may be uncomfortable and fear that the knowledge they share may be incorrect (Kimmerle et al. 2008) or of poor quality (Gammelgaard 2004). In order for employees to have an incentive to share their knowledge, the expected benefits (i.e. rewards or appreciation by colleagues) must be perceived higher than the cost (Casimir et al. 2012). Kimmerle et al. (2008) argue that employees who strongly identify with the organization are more likely to share their knowledge since they adopt the organizational goals as their own. So, depending on the individual employees' position in the organization and many other factors, the level of social dilemma will vary when sharing knowledge.

\subsection{Factors influencing knowledge sharing}

Previous literature has identified a wide range of factors affecting employees' knowledge sharing behavior across different industry sectors and business cultures. Based on an extensive overview of qualitative and quantitative studies we have identified a number of factors that impact knowledge sharing behavior. As in Lin (2007), we have classified them along three dimensions: individual, organizational and technological. In line with this classification, an analysis of literature review of critical success factors for KM found that even more that 50 per cent of the frameworks named human factors and technology as critical success factors. More than 40 per cent named "organization" as additional critical success factor (Heisig 2009).

\subsubsection{Individual factors}

The concept of motivation and knowledge sharing behavior of employees has frequently been discussed using self-determination theory (Deci and Ryan 2000). Deci and Ryan distinguish between two types of motivation, based on different goals, reasons that give rise to an action: extrinsic and intrinsic motivation.

Intrinsic motivation refers to motivation that is driven by an interest or enjoyment of the task itself or enjoying helping others, and exists within the individual rather than relying on any external pressure or reward. People who are intrinsically motivated are more likely to engage in the task, as well as work to improve their skills, which will increase their capabilities as well as the organization's productivity (Deci and Ryan 2000). 
Extrinsic motivation refers to the performance of an activity that leads to a desirable outcome. It focuses on goal-driven reasons, such as monetary rewards and career advancement (Deci and Ryan 2000). Extrinsic motivation is typically based on the perception of the cost (effort) and benefit (reward) associated with sharing knowledge. If the perceived benefits exceed or equal the cost, knowledge sharing will happen. As a consequence, many organizations have introduced reward systems for motivating the employees to share knowledge. Intrinsic and extrinsic motivation have been used in previous KM studies as drivers or determinants of knowledge sharing behavior (Wang and Hou 2015).

Among these individual drivers that impact knowledge sharing intentions are enjoying helping others, e.g. (Ma and Chan 2014, Wasko and Faraj 2005, Hung et al. 2011, Chennamaneni et al. 2012), knowledge self-efficacy (Van Acker et al. 2014), and expected organizational rewards and reciprocal benefits (Jeon et al. 2011, Chennamaneni et al. 2012, Lin 2007). Self-efficacy is defined as "the belief in one's capabilities to organize and execute courses of actions required to manage prospective situations" (Hsu et al. 2007, Bandura 1997). Among the barriers to knowledge sharing, fear has been identified as an important factor that prevents knowledge sharing behavior. Scholarly written articles have included various types of fear (e.g. fear of criticism, fear of giving up power and authority, fear that job security will be reduced, fear of exploitation, fear of personal feedback, fear of losing face or misleading community members (Ardichvili et al. 2003, Šajeva 2007, Matschke et al. 2014). Lack of time or the time required to engage in knowledge sharing has also been presented in different studies as an important factor that may affect the frequency with which knowledge is shared using social media e.g. (Razmerita et al. 2014).

Trust has also been recognized as a factor influencing knowledge sharing. It can be discussed at both the individual level (as an interpersonal trust) and at organizational or different social levels e.g. (Hau et al. 2013, Chow and Chan 2008). Trust can be defined as the belief that another party will behave as expected and not take advantage of the situation (Gefen et al. 2003, Hsu et al. 2007). Social trust influences the interaction between employees; how much they want to learn from each other and share their knowledge (Chow and Chan 2008). According to (Hsu et al. 2007), who discuss trust in virtual communities, trust can be classified into economy-based trust, information-based trust, and identification-based trust. Economy-based trust (e.g. joining a virtual community) saves time and cost in obtaining information, and will also improve own capabilities. Information-based trust refers to security of personal information and trust that the information shared won't be misused. Identification-based trust refers to the possibility to freely discuss personal issues to which you expect a constructive response. 


\subsubsection{Organizational factors}

Organizational culture or corporate culture refers to values, beliefs, and systems that may encourage or impede knowledge creation and sharing within organizations (Newell et al. 2009, Janz and Prasarnphanich 2003, Alavi and Leidner 2001, Michailova and Minbaeva 2012). Each organization has a unique culture that reflects the organization's identity along two dimensions: visible and invisible (Al-Alawi et al. 2007). The visible culture encompasses espoused values, mission and philosophy of the organization, which develops over time. The invisible part relates to the norms and values of the employees that guide their behavior and actions.

Organizations should support and encourage their employees to share and create knowledge (Holsapple and Joshi 2000, Roda et al. 2003). Organizational culture is recognized to be an important factor for the adoption of information systems (Jackson 2011, Hung et al. 2011) and for the creation of a learning organization. Organizational culture and a friendly relationship among employees may also shape their motivation to contribute their knowledge (Hung et al. 2011). Previous studies have shown that there are many factors that encourage knowledge sharing and provide an incentive to adopt new ways of communicating via the social media, the most important being training and reward systems (Paroutis and Al Saleh 2009, Razmerita et al. 2009), management support, guidelines for contributions and an assigned responsible person (Kirchner et al. 2008, Matschke et al. 2014). Furthermore, for successful implementation of knowledge sharing practices through new systems, change of behavior and change management may be necessary (Kuettner et al. 2013, Roda et al. 2003). Other studies have emphasized that a lack of strategy and unclear business objectives or lack of perceived benefits for the users act as barriers to knowledge sharing (Mukamala and Razmerita 2014). Furthermore, beyond these factors we need to remember that national cultural factors (e.g. collectivism) may impact individual knowledge sharing behavior (Zhang et al. 2014) as well as organizational culture. Several authors have investigated knowledge sharing in different national cultures e.g. (Vuori and Okkonen 2012, Mukamala and Razmerita 2014, Jeon et al. 2011, Michailova and Minbaeva 2012).

National culture is related to organizational culture. The study provided by Lauring (2009) emphasized that organization culture is very powerful and influences daily work practices. Knowledge is also bound to social structures and belongs to local communities of practice. Therefore it does not flow freely regardless of power relations. Lauring found that similar employees tend to interact more with each other than with non-similar employees. The study of a Danish MNC conducted by (Michailova and Minbaeva 2012) investigates how core organizational values, which are an important part of the organizational culture, impact knowledge sharing behavior of employees. Organizational values formulated by top management in headquarters based on shared 
beliefs and assumptions are often culturally bound. In addition, the study emphasizes that status inequality may be a major barrier to knowledge sharing that may impact both employees and managers.

According to Hofstede et al. (2010) Danes, as western society, are considered to be very individualistic, very curious and open to innovation. In his analysis Danes have an egalitarian mindset and believe in independence, equal rights, accessible superiors and that management facilitates and empowers. Power is decentralized and managers rely on the experience of their team members. Workplaces have a very informal atmosphere with direct and involving communication. Managers strive for consensus, people solidarity and quality in their working lives. The Law of Jante (Sandemose 1953), also known as the "who do you think you are?" attitude, criticizes individuals' success and achievement as unworthy and inappropriate. Standing out from your colleagues and group is not considered as appropriate behavior. This study is particular relevant especially that Denmark is one of the most advanced knowledge economies and, according to a World Bank study, Denmark was ranked the $3^{\text {rd }}$ place among the knowledge economies in the world (Bank 2012).

\subsubsection{Technological factors}

Technology has been recognized as an important enabler for managing knowledge and knowledge sharing in organizations. The use of technology has been associated with factors such as functionality, usability (Kirchner et al. 2008), "it takes too much time and effort" to contribute (Vuori and Okkonen 2012), structure of the platform (Matschke et al. 2014), "interface design and user needs" (Hung et al. 2011) and consequently has been identified as a significant factor for employees' knowledge sharing.

Enterprise social media is a facilitator of new ways of working along with new forms of knowledge sharing and interactions (Razmerita et al. 2016). However within this study we investigate primarily the main technological factors acting as barriers towards the adoption of social media at work. Our study has included a limited number of technological factors: the usability of the platform, the training provided for using it or the lack of training, information overload, lack of understanding of social media and its benefits. In line with social dilemma, we assume that technology may improve both information self-efficacy, connective efficacy and employees' level of cooperation but may also demotivate users (e.g. when the cost of contributing is high) (Cabrera and Cabrera 2002). 


\subsection{Research model}

Based on the findings from the literature review presented above, a research model was constructed. For each group described in the research model shown in figure 1, we included a number of factors related to knowledge sharing from our literature review, as presented in Table 1 and described in the previous section. The "frequency of knowledge sharing" accounts for how often employees share knowledge and is measured on a five-point-Likert-Scale (1=very frequently (several times a day), $2=$ frequently (daily), $3=$ occasionally (weekly), $4=$ rarely (monthly), $5=$ never). We expect that a person who shares knowledge more often within the organization, is more motivated to share knowledge. Therefore, we define "frequency of knowledge sharing" as dependent variable to quantify the motivation to share knowledge. As independent variables, we have included individual and organizational factors and only a limited number of technological factors (as discussed in the previous section and summarized in Table 1). The questionnaire was focused on knowledge sharing within organization, and in particular on knowledge sharing with social media. As presented in Figure 1 and Table1, these factors are divided into drivers and barriers. In line with social dilemma theory, "increasing the payoff" function, increasing the group or organizational identity and personal responsibility represented as drivers in the research model will more likely lead to a cooperation strategy while the costs or barriers of knowledge sharing are more likely going to lead to a lack of engagement or a "defecting strategy" (Cabrera and Cabrera 2002). Through training and good usability, technology may increase the efficacy of contributing while the lack or training or poor usability may constitute a barrier towards increasing the efficacy of contributing and thus lead to a defecting strategy. Good usability is associated with the ease of use and learnability of technology. In addition, the model took into consideration demographics. The demographic factors included are age, gender, position in the company, years of experience in the organization e.g. (Riege 2007, Michailova and Minbaeva 2012). 


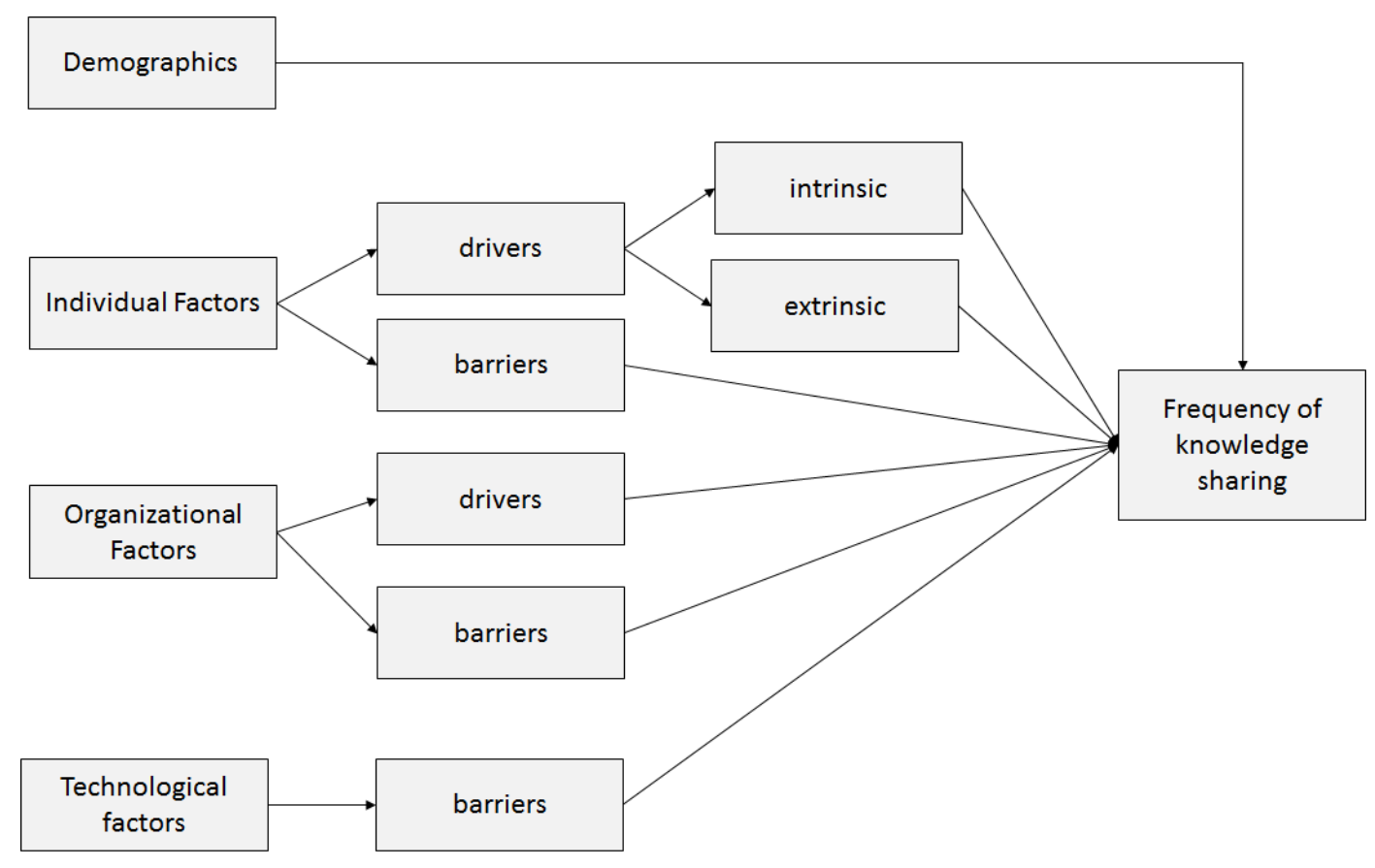

Figure 1: Research Model: Factors influencing the frequency of knowledge sharing

Table 1 presents an overview of the different independent variables considered in the model presented in Figure 1 and outlines the items considered for each group of factors.

Table 1: Items considered for the research model

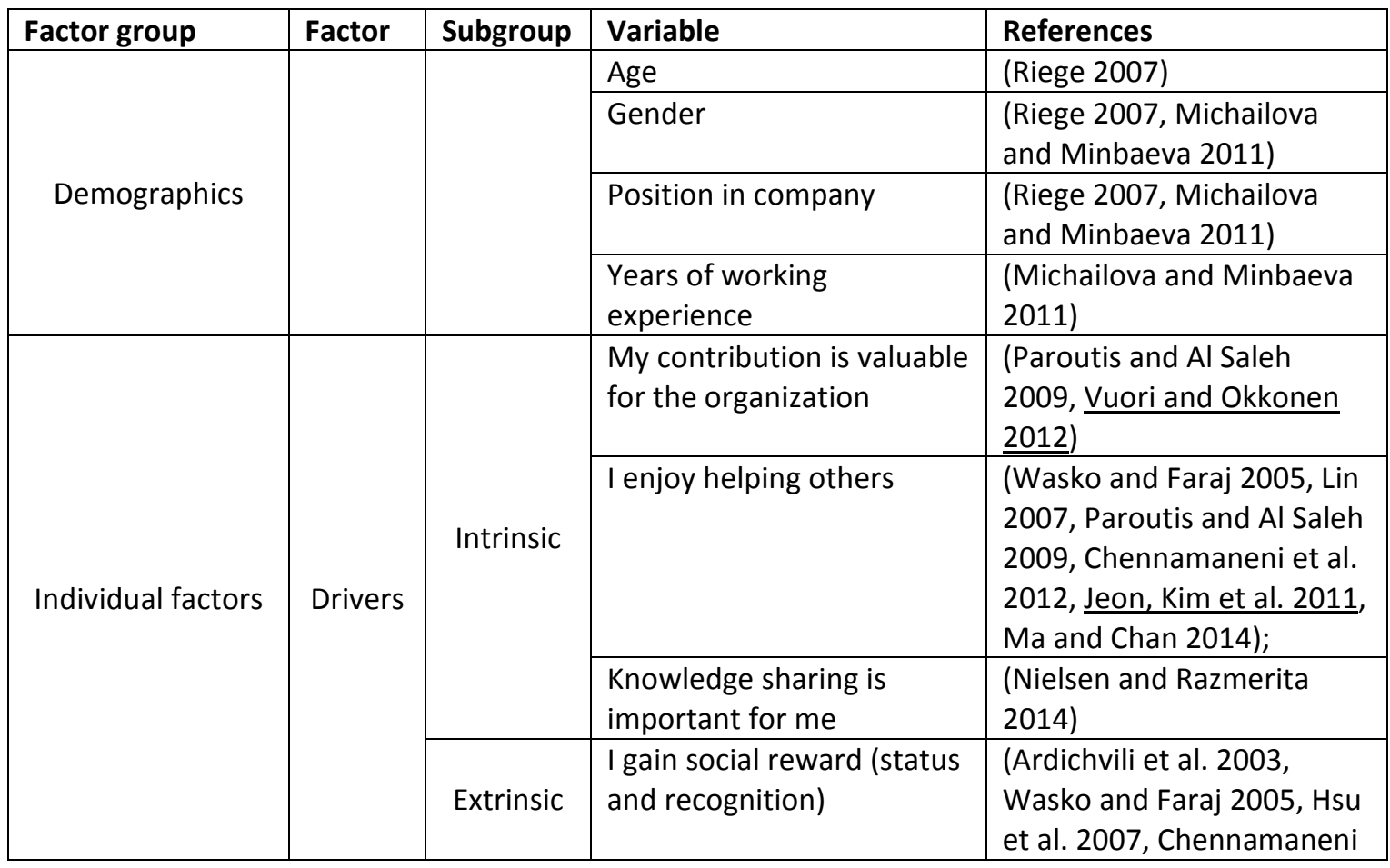




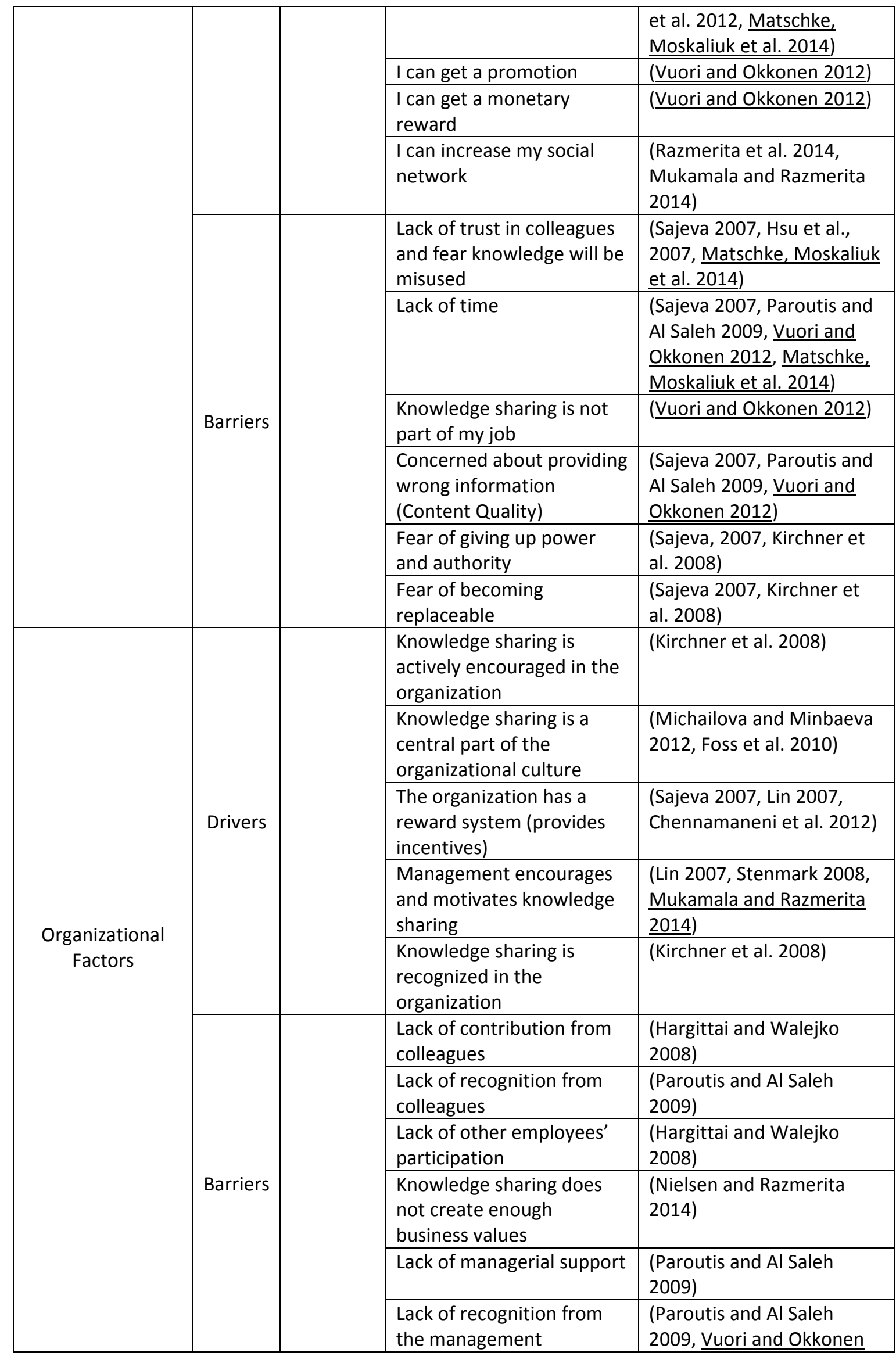




\begin{tabular}{|c|c|c|c|}
\hline & & & 2012) \\
\hline & & $\begin{array}{l}\text { Lack of management } \\
\text { commitment }\end{array}$ & (Sajeva 2007); \\
\hline & & $\begin{array}{l}\text { Change of behavior: from } \\
\text { hoarding to sharing }\end{array}$ & $\begin{array}{l}\text { (Paroutis and Al Saleh } \\
\text { 2009, Roda, Angehrn et al. } \\
\text { 2003, Kuettner, Diehl et al. } \\
\text { 2013) }\end{array}$ \\
\hline \multirow{4}{*}{$\begin{array}{l}\text { Technological } \\
\text { Factors }\end{array}$} & \multirow{4}{*}{ Barriers } & $\begin{array}{l}\text { Lack of training for using } \\
\text { social media platforms }\end{array}$ & $\begin{array}{l}\text { (Sajeva 2007, Paroutis and } \\
\text { Al Saleh 2009, Matschke, } \\
\text { Moskaliuk et al. 2014) }\end{array}$ \\
\hline & & $\begin{array}{l}\text { Poor usability - "too } \\
\text { complicated to use" }\end{array}$ & $\begin{array}{l}\text { (Lin 2007, Sajeva 2007, } \\
\text { Vuori and Okkonen 2012) }\end{array}$ \\
\hline & & $\begin{array}{l}\text { Lack of understanding } \\
\text { social media and its } \\
\text { benefits }\end{array}$ & (Vuori and Okkonen 2012) \\
\hline & & Information overload & $\begin{array}{l}\text { (Sajeva 2007, Paroutis and } \\
\text { Al Saleh 2009) }\end{array}$ \\
\hline
\end{tabular}

\section{Data and method}

\subsection{Data collection methodology}

The research model presented in Figure 1, as output of the literature review (described in section 2), has been tested with a concurrent design in a mixed method tradition (Teddlie and Tashakkori 2006, Creswell et al. 2003). In concurrent design, data collection occurs in parallel or synchronous manner independent of each other (Venkatesh et al. 2013). The study follows a confirmatory-explanatory approach. Qualitative data is used to elaborate and explain quantitative results.

The study aimed to get insights into knowledge sharing in Danish companies focusing on new forms of knowledge sharing using social media. Quantitative data was collected through an online survey questionnaire consisting of 15 questions covering individual, organizational and technological items as presented in Table 1. As indicated earlier and as presented in Table 1, most of the questions are derived based on the literature review. The survey asked how often employees share knowledge, which means they use for knowledge sharing, how often they use social media, for which purposes, how does knowledge sharing through social media provides business value and what motivates (the drivers) or what prevents them to share knowledge with social media (the barriers) within their organization. Furthermore we were interested in how or whether knowledge sharing is encouraged. In order to reduce social desirability bias, the survey did not include any personal identification of the individuals and the quantitative analysis of the data was restricted at an aggregated level. The survey was pretested and revised prior to its distribution in order to avoid interpretation errors and to increase the clarity of questions. 
For collecting answers, we have contacted seven companies using social media for internal communication but only five responded. The companies are from various industry sectors like telecommunications, media and marketing, banking and financial services and shipping and logistics. The link to the questionnaire was sent to the person responsible for social media initiatives or knowledge management in each of the organizations. These employees agreed to distribute the survey among their colleagues thus we cannot report about the response rate. Additionally, the link to the questionnaire was published on several social networks. From that, we received few answers from employees from six more SMEs. Twelve of the respondents did not report their company name.

A total of 116 responses were collected over a four-month period. Out of 116 answers 114 were valid. Most of the survey questions were designed as multiple choice questions and therefore the answers were mostly of a nominal nature. In order to identify the significant factors that influence the frequency of knowledge sharing and the usage of social media for knowledge sharing, the Chi ${ }^{2}$ test method was used. This test is used to examine whether two variables are independent (that they are not related). Additionally, in order to evaluate the strength of the relationship between the dependent variable and the independent ones, Cramer's V was applied.

In addition eight semi-structured interviews were conducted with four managers and four employees' from four organizations providing the majority of responses in the survey. Managers were responsible for social media or knowledge management initiatives. Employees were active users of the social media platforms. The interviews were conducted with the aim to get additional insights into employees' knowledge sharing behavior and their opinion about the use of social media in a work context. The interview guideline consisted of a subset of the survey questions, including nine open-ended questions and sub-questions. Appendix 1 provides an overview of the main questions used for the employees' interviews. The interviews were conducted in Danish either face-to-face or over the phone over a time frame of approximately 45 minutes. The interview questions for the managers and the employees were different as it was assumed that they might have different perspectives on knowledge sharing due to their different roles and responsibilities. Appendix 2 provides an overview of the main questions used for the managers. The questions for the managers focused on their views into knowledge sharing issues faced within the organization as well as the strategic adoption and use of social media platforms for knowledge sharing and internal communication.

\subsection{Data Analysis}

As stated earlier, the data sample comprises 114 respondents from employees regardless of their role and position within organizations engaged in social media for internal communication. The 
majority of respondents are from two medium sized organizations (64.5\%), $18 \%$ of respondents from other SMEs, 7\% from two of the 20 biggest companies in Denmark and 10.5\% did not disclose the name of their organization. As shown in Table 2, most of the respondents were below 50 years of age, and more men $(56.9 \%)$ than women $(41.4 \%)$ responded. The majority of respondents were young professionals who had a working experience of less than 5 years, employed as knowledge workers at different levels in organizations. As to the level in the organization, $20.7 \%$ were managers, $46.6 \%$ consider themselves as specialists in their areas, while $20.7 \%$ were office workers and $4.3 \%$ were trainees.

Table 2: Descriptive Statistics of Respondents

\begin{tabular}{lr}
\hline Age & Frequency (\%) \\
\hline Younger than 30 & $25(21.6 \%)$ \\
$30-39$ & $48(41.4 \%)$ \\
$40-49$ & $34(29.3 \%)$ \\
over 49 & $8(6.9 \%)$ \\
Missing & $1(0.9 \%)$ \\
\hline Gender & Frequency (\%) \\
\hline Male & $66(56.9 \%)$ \\
Female & $48(41.4 \%)$ \\
Missing & $2(1.7 \%)$ \\
\hline Position & Frequency (\%) \\
\hline Manager & $24(20.7 \%)$ \\
Specialist & $54(46.6 \%)$ \\
Office Worker & $24(20.7 \%)$ \\
Trainee & $5(4.3 \%)$ \\
Other & $9(7.7 \%)$ \\
\hline Working experience & Frequency (\%) \\
\hline$<1$ year & $2(1.7 \%)$ \\
$1-5$ years & $81(69.8 \%)$ \\
$5-10$ years & $18(15.5 \%)$ \\
$10-15$ years & $9(7.8 \%)$ \\
More than 15 years & $3(2.6 \%)$ \\
Missing & $3(2.6 \%)$ \\
&
\end{tabular}

In relation with the question how the usage of technology influences knowledge sharing, employees use different means and tools to share knowledge, as shown in Figure 2. Employees primarily share knowledge through traditional network channels like email, face-to-face meetings, chat and intranet, whereas the adoption and use of enterprise social media including blogs, wikis, Google docs and enterprise social networks platforms (such as Yammer, Chatter, Podio or other customized social 
platforms) is limited. As can be seen in figure 2, enterprise social networks (like Yammer and Podio) are used by $40 \%$ of respondents of the survey while email is used by $90 \%$ of the respondents.

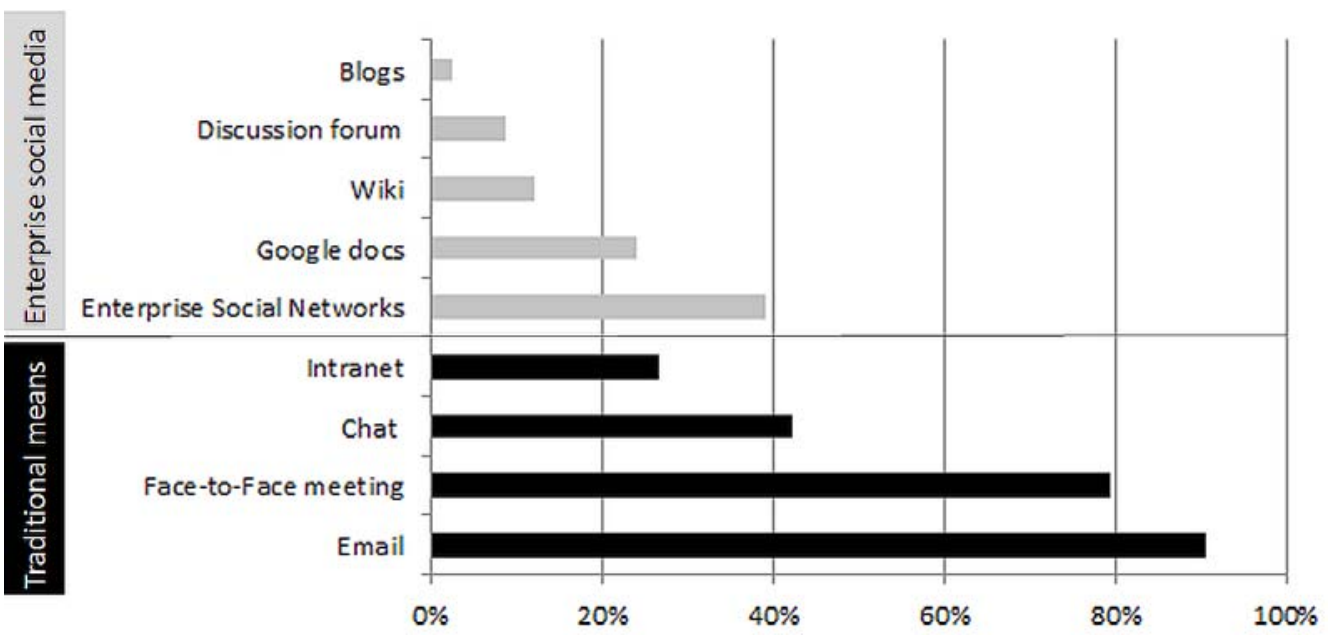

Figure 2: Knowledge sharing means and technologies

An overview of different purposes of using social media is provided in Fig. 3. According to the survey results, employees engaged on enterprise social media use it primarily for communicating, learning and exchanging news within organizations. The amount of respondents engaged within social media amounts to $45 \%$ of the respondents.

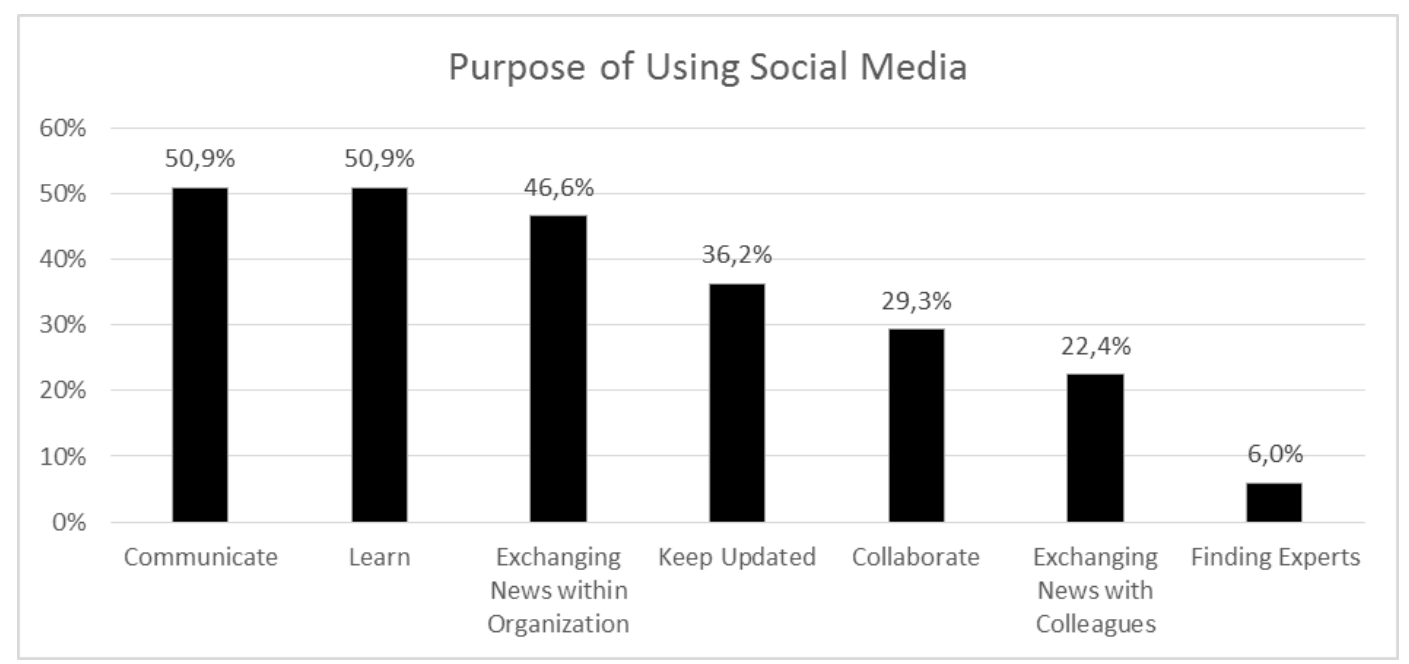

Figure 3: Purposes of Knowledge Sharing with Social Media

Half of the respondents communicate and learn with social media support. Exchanging news within the organization, keeping updated with news, and collaborating also play a major role within social 
media communication. However, finding experts on social media is only relevant for $6 \%$ of the respondents.

\section{Findings}

\subsection{Knowledge sharing framework}

The study results focusing on factors influencing knowledge sharing behavior are presented below. The factors influencing knowledge sharing that have been considered for the research model along with the percentages of responses are presented in Table 3. Nearly all survey participants $(97.4 \%)$ consider knowledge sharing as important, $87.9 \%$ consider their contribution valuable for their organization and $71.1 \%$ state that knowledge sharing is recognized by the organization. Only a small number of participants fear that their shared knowledge will be misused (6\%), or that they will become replaceable (4.3\%).

Table 3: Overview of factors influencing knowledge sharing and provided responses

\begin{tabular}{|c|c|c|c|}
\hline Individual factors & Percentages & Organizational factors & Percentages \\
\hline $\begin{array}{l}\text { My contribution is valuable for } \\
\text { the organization }\end{array}$ & $87.9 \%$ & $\begin{array}{l}\text { Knowledge sharing is actively } \\
\text { encouraged in the organization }\end{array}$ & $42.1 \%$ \\
\hline I enjoy helping others & $64.7 \%$ & $\begin{array}{l}\text { Knowledge sharing is a central } \\
\text { part of the organizational culture }\end{array}$ & $43.1 \%$ \\
\hline $\begin{array}{l}\text { Knowledge sharing is important } \\
\text { for me }\end{array}$ & $97.4 \%$ & $\begin{array}{l}\text { The organization has a reward } \\
\text { system (provides incentives) }\end{array}$ & $5.2 \%$ \\
\hline $\begin{array}{l}\text { I gain social reward (status and } \\
\text { recognition) }\end{array}$ & $33.6 \%$ & $\begin{array}{l}\text { Management encourages and } \\
\text { motivates knowledge sharing }\end{array}$ & $32.8 \%$ \\
\hline I can get a promotion & $8.6 \%$ & $\begin{array}{l}\text { Knowledge sharing is recognized in } \\
\text { the organization }\end{array}$ & $71.1 \%$ \\
\hline I can get a monetary reward & $10.3 \%$ & $\begin{array}{l}\text { Lack of contribution from } \\
\text { colleagues }\end{array}$ & $37.9 \%$ \\
\hline I can increase my social network & $25.0 \%$ & $\begin{array}{l}\text { Lack of recognition from } \\
\text { colleagues }\end{array}$ & $34.5 \%$ \\
\hline $\begin{array}{l}\text { Lack of trust in colleagues and } \\
\text { fear knowledge will be misused }\end{array}$ & $6.0 \%$ & $\begin{array}{l}\text { Lack of other employees' } \\
\text { participation }\end{array}$ & $35.3 \%$ \\
\hline Lack of time & $47.4 \%$ & $\begin{array}{l}\text { Knowledge sharing does not } \\
\text { create enough business values }\end{array}$ & $1.7 \%$ \\
\hline $\begin{array}{l}\text { Knowledge sharing is not part a of } \\
\text { my job }\end{array}$ & $6.0 \%$ & Lack of managerial support & $29.3 \%$ \\
\hline $\begin{array}{l}\text { Concerned with providing wrong } \\
\text { information (Content Quality) }\end{array}$ & $13.8 \%$ & $\begin{array}{l}\text { Lack of recognition from the } \\
\text { management }\end{array}$ & $34.5 \%$ \\
\hline $\begin{array}{l}\text { Fear of giving up power and } \\
\text { authority }\end{array}$ & $4.3 \%$ & Lack of management commitment & $31.9 \%$ \\
\hline Fear of becoming replaceable & $4.3 \%$ & $\begin{array}{l}\text { Change of behavior: from } \\
\text { hoarding to sharing }\end{array}$ & $11.2 \%$ \\
\hline
\end{tabular}




\begin{tabular}{|l|l|l|l|}
\hline Technological Factors & Percentages & & \\
\hline $\begin{array}{l}\text { Lack of training for using social } \\
\text { media platforms }\end{array}$ & $17.2 \%$ & & \\
\hline $\begin{array}{l}\text { Usability - "too complicated to } \\
\text { use" }\end{array}$ & $16.4 \%$ & & \\
\hline $\begin{array}{l}\text { Lack of understanding social } \\
\text { media and its benefits }\end{array}$ & $19.8 \%$ & & \\
\hline \begin{tabular}{l} 
Information overload \\
\hline
\end{tabular} & $26.7 \%$ & & \\
\hline
\end{tabular}

A knowledge sharing framework of influencing factors was consequently built on the basis of the $\mathrm{Chi}^{2}$-Test. Figure 4 shows the statistically significant factors (sig. level $=0.05\left({ }^{*}\right)$ and $0.01\left({ }^{* *}\right)$ ) that impact the dependent variable (frequency of knowledge sharing) according to $\mathrm{Chi}^{2}$. For the calculation of the strength of influence of the significant factors, Cramer's V was used. Cramer's V has values between 0 and 1 , with 1 as highest value regarding the strength of relationship.

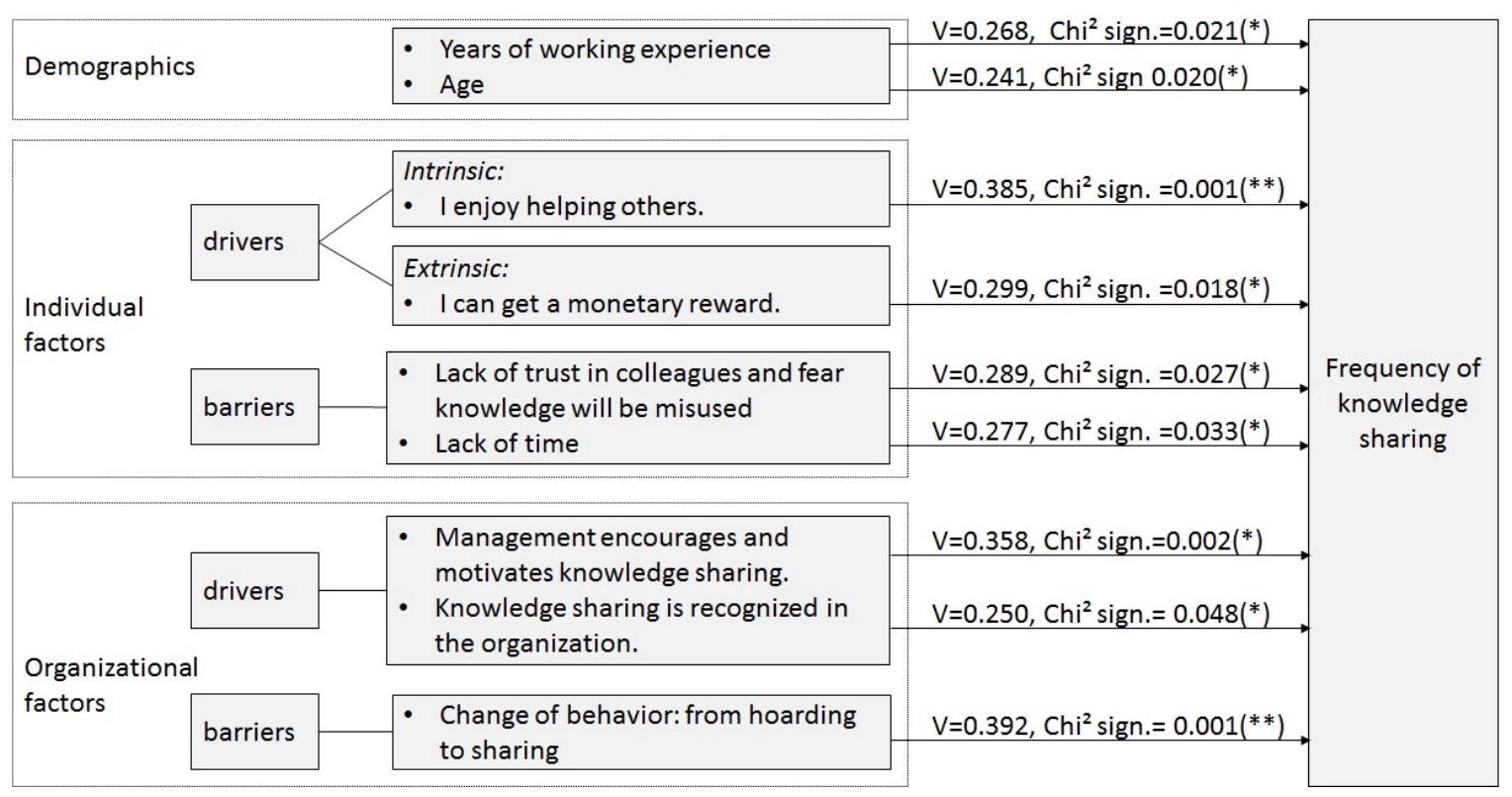

Figure 4: Framework of statistically significant factors that influence frequency of knowledge sharing with enterprise social media

The intrinsic motivation driver in "I enjoy helping others" as well as the barrier "Change of behavior from hoarding to sharing" are the two variables with significance level 0.001 (highly significant). Also, demographics and in particular work experience and age influence the frequency of knowledge sharing. Furthermore, within the category of individual drivers both intrinsic "I enjoy helping others" and extrinsic factors "monetary reward" are significant. Two significant individual barriers have been 
identified: "lack of trust in colleagues" and "lack of time". As regards the strength of influence, "resistance to change of behavior" ( $\mathrm{V}=0.392)$, "enjoy helping others" $(\mathrm{V}=0.385)$ and management encouragement $(\mathrm{V}=0.358)$ have the highest Cramer's $\mathrm{V}$ values, although they have only a lowermedium influence value.

Within the organizational factors, two drivers ("managerial support" and "knowledge sharing recognition") and one barrier, resistance to change ("the change of knowledge sharing behavior"), have a significant influence on the frequency of knowledge sharing (Figure 4). Interestingly, technological factors do not play a significant role for the motivation to share knowledge.

\subsection{Qualitative results}

The results from qualitative interviews provide deeper insights into the individual and organizational factors that impact knowledge sharing behavior. The interviews highlight that employees are both intrinsically and extrinsically motivated to share knowledge but not necessarily through social media platforms. As can be seen in the table below, most of the significant factors are reflected in the quotes extracted from the interviews with the knowledge workers. The only factors that haven't been covered in the interviews are age and the extrinsic motivation "I can get a monetary reward".

Table 4: Overview of significant factors for knowledge sharing and comments from qualitative interviews

\begin{tabular}{|c|c|c|}
\hline Category & Significant Factor & Qualitative results from interviews \\
\hline 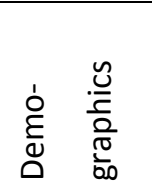 & Years of working experience & $\begin{array}{l}\text { "The platform has been very useful for new } \\
\text { employees to get an overview and keep updated on } \\
\text { what happens in the organization." }\end{array}$ \\
\hline \multirow{2}{*}{ 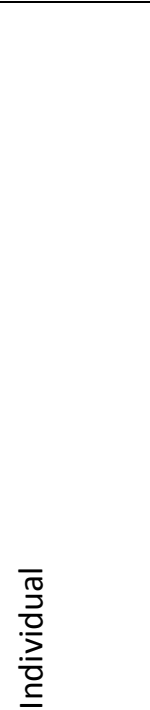 } & I enjoy helping others & $\begin{array}{l}\text { "It does not make sense not to share knowledge } \\
\text { which can be helpful to your colleagues." } \\
\text { "The essence of social media is to share relevant } \\
\text { knowledge with your colleagues. ... You want to } \\
\text { provide value." } \\
\text { "...knowledge sharing can be a fun break away from } \\
\text { working where I spend five minutes on sharing } \\
\text { knowledge which I find interesting and relevant for } \\
\text { my colleagues." }\end{array}$ \\
\hline & $\begin{array}{l}\text { Lack of trust in colleagues and } \\
\text { fear knowledge will be }\end{array}$ & $\begin{array}{l}\text { "A rapidly changing business market and job } \\
\text { insecurity does not encourage knowledge sharing }\end{array}$ \\
\hline
\end{tabular}




\begin{tabular}{|c|c|c|}
\hline & misused & $\begin{array}{l}\text { between employees." } \\
\text { "The new platform creates an excellent way for the } \\
\text { employees to get to know each other in a more } \\
\text { informal way, which in the long run fosters trust and } \\
\text { improved collaboration and knowledge sharing." }\end{array}$ \\
\hline & Lack of time & $\begin{array}{l}\text { "Far from everyone is using the platform. Lack of } \\
\text { time is an issue for both managers and employees." }\end{array}$ \\
\hline & $\begin{array}{l}\text { Management encourages and } \\
\text { motivates knowledge sharing }\end{array}$ & $\begin{array}{l}\text { "Management claims to encourage knowledge } \\
\text { sharing, and at times knowledge sharing seems to be } \\
\text { the solution to all problems. Yet, very few managers } \\
\text { are truly capable of empowering and prioritizing } \\
\text { knowledge sharing." } \\
\text { "Managers don't need to explain the technical } \\
\text { aspect of using the platform, but they should explain } \\
\text { how the platform can provide value to the } \\
\text { employees as well as to the company." }\end{array}$ \\
\hline & $\begin{array}{l}\text { Knowledge sharing is } \\
\text { recognized in the organization }\end{array}$ & $\begin{array}{l}\text { "You become more valuable by sharing knowledge. } \\
\text { You create social capital, and thereby you motivate } \\
\text { and influence people to engage and become } \\
\text { involved, by sharing knowledge that means } \\
\text { something to you". } \\
\text { "Knowledge sharing is a part of my job description, } \\
\text { so I don't feel more motivated just because the } \\
\text { management and managers participate on the } \\
\text { platform." }\end{array}$ \\
\hline 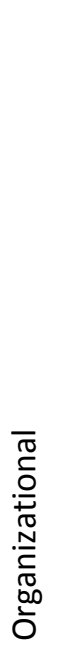 & $\begin{array}{l}\text { Change of behavior: From } \\
\text { hoarding to sharing }\end{array}$ & $\begin{array}{l}\text { "Management tries to create a culture for } \\
\text { knowledge sharing, but it is difficult. People are stuck } \\
\text { in old habits and there is a lack of knowledge sharing } \\
\text { culture in the organization". } \\
\text { "It takes three months to create [a] change [of } \\
\text { behavior] of employees and get them to adopt a new } \\
\text { way of working" } \\
\text { "Many of the employees prefer to use the old ways } \\
\text { of communicating. People are creatures of habit, so } \\
\text { the employees only use the platform a little." }\end{array}$ \\
\hline
\end{tabular}




\begin{tabular}{|l|l|l|}
\hline \multirow{1}{*}{} & $\begin{array}{l}\text { "The top management never had the wish to invest } \\
\text { time to make a cultural change in the company, and } \\
\text { it was important that we didn't take away the } \\
\text { employees' current way of working." }\end{array}$ \\
\hline
\end{tabular}

Although the benefits of using social media are acknowledged, employees' participation on social platforms is still limited. There may be different reasons for this. In one of the interviews, one employee points out: "The majority of data I need for my work I find in other databases." A manager mentions: "I often have confidential knowledge, which I only share face-to-face with management."

Furthermore a lack of strategy or lack of management involvement was mentioned: "There's no knowledge sharing strategy at this point, and top management is not actively involved in promoting the adoption of the platform."

Additionally to the significant factors for knowledge sharing, the usability of the platform plays an important role, although it wasn't significant in the result. One manager from a logistics company believes that employees' motivation to share knowledge may be linked to the fact that the social media platforms are similar to those used in their private lives: "People are willing to learn new things. The social media platforms are recognizable with features from Facebook, LinkedIn and Twitter. And our behavior in the workplace is not necessarily different from our private lives."

A previous study found that that usefulness and the benefits of using social platforms have to outweigh the costs of spending time and effort on sharing knowledge (Mukamala and Razmerita 2014). In other words, the use of the social media platform needs to be relevant and fun for the individual employee: "knowledge sharing can be a fun break away from working". In line with previous findings, the management needs to consider costs and benefits at both individual and organizational levels (Razmerita et al. 2014). This finding is consistent with the study conducted by e.g. (Hung et al. 2011, Paroutis and Al Saleh 2009) which identified perceived usefulness as one of the key factors which affect employees' knowledge sharing. If employees do not perceive the benefits of adopting such tools or they are not explained or communicated why it is important to adopt such tools than they are less likely to use them on regular basis.

Knowledge sharing behavior can be also influenced by national culture. A comment from a manager at a media company indicates how national cultural elements like the Danish 'Jantelov' may influence knowledge sharing negatively: "Some employees may hoard knowledge, since they do not want to come across as sucking up to management and managers by sharing knowledge too frequently on the platform. This tendency is not prevalent on external platforms, such as Facebook and Twitter, but more likely in a business environment." 
The presence of the management and managers on such platforms does not seem to be a motivating factor for some employees; even though some employees expect managers to be involved and play a leading role in communication and using these platforms.

\subsection{Connecting social dilemma, knowledge sharing framework and interventions}

An overview of type of interventions suggested to overcome knowledge sharing dilemma, extending interventions from (Cabrera and Cabrera 2002) in connection with significant items found in our study are presented in Table 5.

Table 5: Overview of significant items for knowledge sharing in line with social dilemma theory and examples for interventions

\begin{tabular}{|c|c|c|}
\hline Significant items & $\begin{array}{l}\text { Connection to social dilemma } \\
\text { theory }\end{array}$ & $\begin{array}{l}\text { Interventions / } \\
\text { Recommendations }\end{array}$ \\
\hline I can get a monetary reward. & $\begin{array}{l}\text { Restructuring the payoff } \\
\text { function }\end{array}$ & $\begin{array}{l}\text { Increase or make visible the } \\
\text { benefits of contributing }\end{array}$ \\
\hline Lack of time & $\begin{array}{l}\text { Restructuring the payoff } \\
\text { function }\end{array}$ & $\begin{array}{l}\text { Include knowledge sharing as part } \\
\text { of (daily) working routine }\end{array}$ \\
\hline $\begin{array}{l}\text { Lack of trust in colleagues } \\
\text { and fear knowledge will be } \\
\text { misused. }\end{array}$ & $\begin{array}{l}\text { Increasing the group identity } \\
\text { and personal responsibility }\end{array}$ & $\begin{array}{l}\text { Team building and increase sense } \\
\text { of organizational community } \\
\text { Increase identifiability with } \\
\text { organization and its members }\end{array}$ \\
\hline I enjoy helping others & Intrinsic factor & $\begin{array}{l}\text { Recognize and reward social } \\
\text { oriented individuals. }\end{array}$ \\
\hline $\begin{array}{l}\text { Management encourages } \\
\text { and motivates knowledge } \\
\text { sharing }\end{array}$ & $\begin{array}{l}\text { Promote the group identity and } \\
\text { personal responsibility }\end{array}$ & $\begin{array}{l}\text { Communicate and make potential } \\
\text { value of shared knowledge greater } \\
\text { than individual costs } \\
\text { Increase team orientation rather } \\
\text { individual competition. }\end{array}$ \\
\hline $\begin{array}{l}\text { Knowledge sharing is } \\
\text { recognized in the } \\
\text { organization }\end{array}$ & $\begin{array}{l}\text { Promote the group identity and } \\
\text { personal responsibility }\end{array}$ & $\begin{array}{l}\text { Encourage communication and } \\
\text { ensure a critical s participants } \\
\text { Publish information about } \\
\text { employees' contributions and } \\
\text { provide feedback to contributors }\end{array}$ \\
\hline $\begin{array}{l}\text { Change of behavior: From } \\
\text { hoarding to sharing }\end{array}$ & $\begin{array}{l}\text { Personal responsibility and } \\
\text { Increase efficacy of }\end{array}$ & $\begin{array}{l}\text { Communicate/increase the } \\
\text { benefits of contributing and value }\end{array}$ \\
\hline
\end{tabular}




\begin{tabular}{|l|l|l|}
\hline & contributing & $\begin{array}{l}\text { of collective gain } \\
\text { Training, reduce the cost of } \\
\text { contributing. }\end{array}$ \\
\hline
\end{tabular}

In line with social dilemma theory, a "worst case scenario" will be when all employees behave to maximize their utility without the existence of social norms (Wilkesmann et al. 2009) personal responsibility, altruistic behaviors, or managerial interventions. Intrinsically motivated employees are more likely to share and transfer knowledge as "they enjoy helping others".

The absence of cooperation or lack of engagement in active knowledge sharing seems might require a change of behavior especially when new innovative technologies such as social media are introduced. The absence of cooperation, lack of engagement or free riding is not necessary a defection (Wilkesmann et al. 2009) since most employees answered that "knowledge sharing is important for me" (97.4\%). However lack of time, lack of trust in colleagues and fear that knowledge will be misused specific to highly competitive environments, might lead to a situation similar to the "tragedy of the commons" or "prisoner's dilemma".

\section{Conclusions and Implications}

\subsection{Summary of findings}

Social media platforms also referred to as enterprise social media can enhance work practices and enable new ways of knowledge sharing in organizations, and thereby increase the organization's competitiveness. Furthermore, these platforms provide new opportunities for organizations to connect employees, who can then benefit from the valuable knowledge exchanges (especially the tacit knowledge of employees). However, these social platforms are not a panacea for knowledge sharing and collaboration, as the majority of the respondents still use traditional communication forms such as email and face to face meetings.

This article has investigated employees' motivation to share knowledge using social media with the aim of determining which factors (individual, organizational and technological as presented in Table1) affect employees' knowledge sharing behavior (measured as the frequency). Given that social media communication within organizations is an emerging phenomenon, our framework, showed in Figure 4, offers a comprehensive set of factors that need to be considered by management to increase engagement in using social media at work. The framework highlights statistically significant organizational and individual motivational factors under which employees 
change their choice from a free rider position to a cooperative strategy in which they share knowledge. The key finding was that knowledge sharing is not a real "social dilemma", but knowledge workers see the importance of knowledge sharing and the altruistic behavior "I enjoy helping others" is the most important factor that impact the frequency of knowledge sharing. Other significant factors influencing contributing behavior are: "I can get a monetary reward", "Management encourages and motivates knowledge sharing" and "Knowledge sharing is recognized in the organization". The biggest identified challenge is "the change of behavior from hoarding to sharing knowledge". Other significant barriers in knowledge sharing are: "lack of time" and "lack of trust in colleagues and fear knowledge will be misused".

\subsection{Research limitation and future work}

The study has a number of limitations. The empirical data is limited to 114 respondents from 13 organizations from Denmark. This tendency may be unique to knowledge sharing in Danish or Scandinavian companies. Future work could include a larger sample and the selection of more organizations from other sector of activities and other countries. Further research should be done on cultural influences which may affect employees' knowledge sharing and knowledge sharing through social media in other countries and compare the findings. The proposed framework is comprehensive but considers only a limited number of technological factors. It is worth mentioning that the technological factors that were investigated did not play a significant role as a social media and knowledge sharing driver. However future work could also include a number of additional factors such as interface design, security and sensitivity of knowledge and quality of knowledge. Despite its current limitations, the study has potentially important implications for the knowledge sharing governance and in particular for understanding the individual and organizational factors that influence social media communication within organizations.

\subsection{Implications for research}

This study has incorporated a motivational perspective into the factors that influence knowledge sharing behavior. The focus was on the individual and organizational factors. In particular, the article examines intrinsic and extrinsic motivations as key factors that influence the frequency of knowledge sharing. Employees' behavior and decision to withhold information can be understood using a costbenefit analysis. Taking a social dilemma perspective, knowledge sharing or "exchanging information" represents a "public goods dilemma". Contribution of information or knowledge may be perceived as a loss of individual power and reduced social influence, especially in anonymous situation in which a contributor cannot expect to gain recognition (Cress et al. 2006). "Fear of giving 
up power and authority" scores very low (4.3\%) in our survey and is not identified as a significant factor. We found a positive attitude of employees' towards knowledge sharing because they consider sharing knowledge to be more beneficial than to hoard it, which defies the rationality of 'social dilemma' theory. Most of the employees are aware of the importance of knowledge sharing („Knowledge sharing is important for me" 97.4\%, „Knowledge sharing is recognized in the organization" $71.1 \%$ in Table 3 ) and motivated to cooperate in achieving collective goals with the other organizational members („My contribution is valuable for the organization“ $87.9 \%$ ). This finding could be explained by the fact that higher education plays an instrumental role in fostering abilities required for today's knowledge workers, including knowledge sharing dispositions and good citizenship among graduates (Blasco and Tackney 2013). In addition to the perceived benefits, the costs of knowledge sharing have to be considered. Based on the quantitative data analysis, the main barriers towards social media communication have been identified: the lack of trust ("fear that knowledge will be misused"), the lack of time and resistance to change of behavior (especially if employees need to change their current work practices).

Social Media communication competes with the daily tasks an employee has to do and therefore this might cause a situation employees save time and other "costs" if they do not contribute anything at all. According to our study, employees' dilemma whether to share or not to share knowledge may be influenced by both external incentives (e.g. monetary rewards, recognition) and also by internally invoked incentives (e.g. management support and involvement, organizational culture). Both qualitative and quantitative data indicate that the management plays a critical role for knowledge sharing using traditional means and social media.

\subsection{Managerial Implications}

The identification of both motivational drivers and barriers can help shed light on how managers in organizations can motivate employees to interact and share knowledge in a work context. As presented in the model, employees are both intrinsically and extrinsically motivated to share knowledge. For a majority of participants involved in this study knowledge sharing seems to be an integral part of their job, and they find it important to share knowledge in order to provide value to the organization and their colleagues.

The study has identified "I enjoy helping the others" as the most important factor that influences knowledge sharing behavior. This finding is in line with previous research, e.g. (Hung et al. 2011, Wasko and Faraj 2005, Jeon et al. 2011, Chennamaneni et al. 2012) who identified altruism as an important antecedent for the intention of knowledge sharing. The study shows that the management has to consider both intrinsic and extrinsic factors that may impact the motivation to adopt such 
platforms (Wang and Hou 2015, Hung et al. 2011, Foss et al. 2010). Furthermore, knowledge sharing should be recognized and valued within the organizations. Both top management support and organizational culture play an important role for the adoption of knowledge sharing behaviors. Managers can play an instrumental role in removing barriers and shaping organizational culture (Hung et al. 2011). Organizational culture through social agreements, shared values and beliefs may define different forms of social control. Thus culture may influence or constraint individual behavior: if I commit to a norm of cooperation, free riding is not an option.

The study suggests that the adoption of social media may imply "a cultural change in the company", a strategy and an investment of time and resources to make such a change. The change of behavior of employees in particular communicating through a new platform like social media is often a challenge for many since it demands a change of current work practices and "habits". According to (Davidson 2006) organizational change programs need to take into account how members of the organization make sense of the technology in order to achieve planned outcomes and to be able to influence their actions.

\section{Acknowledgement}

The authors would like to thank to the JKM editor and the anonymous reviewers for their feedback and support in revising the paper.

\section{References}

Al-Alawi, A.I., Al-Marzooqi, Y.N. and Mohammed, F.Y. (2007), "Organizational culture and knowledge sharing: critical success factors", Journal of knowledge management, Vol. 11 No. 2, pp. 22-42.

Alavi, M. and Leidner, D.E. (2001), "Review: Knowledge Management And Knowledge Management Systems: Conceptual Foundations And Research Issues", Mis Quarterly, Vol. 25 No. 1, pp. 107-36.

Ardichvili, A., Page, V. and Wentling, T. (2003), "Motivation and barriers to participation in virtual knowledge-sharing communities of practice", Journal of knowledge management, Vol. 7 No. 1, pp. 64-77.

Bandura, A. (1997), "Self-efficacy: The exercise of control", in, New York: Freeman.

Bank, W. (2012), "Knowledge Economy Index (KEI) 2012 Rankings, Washington, World Bank", available at: http://siteresources.worldbank.org/INTUNIKAM/Resources/2012.pdf (accessed October, the 5th 2015). 
Blasco, M. and Tackney, C. (2013), "“If it ain't broke, don't fi x it": internationalisation and the erosion of the positive hidden curriculum in Danish higher education1", International Journal of Management in Education 27, Vol. 7 No. 4, pp. 341-59.

Cabrera and Cabrera. (2002), "Knowledge-Sharing Dilemmas", Organization Studies, Vol. 23 No. 5, pp. 687-710.

Cabrera, A. and Cabrera, E.F. (2002), "Knowledge-sharing dilemmas", Organization Studies, Vol. 23 No. 5, pp. 687-710.

Chennamaneni, A., Teng, J.T. and Raja, M. (2012), "A unified model of knowledge sharing behaviours: theoretical development and empirical test", Behaviour \& Information Technology, Vol. 31 No. 11, pp. 1097-115.

Chow, W.S. and Chan, L.S. (2008), "Social network, social trust and shared goals in organizational knowledge sharing", Information \& Management, Vol. 45 No. 7, pp. 458-65.

Cress, U., Kimmerle, J. and Hesse, F.W. (2006), "Information Exchange With Shared Databases as a Social Dilemma The Effect of Metaknowledge, Bonus Systems, and Costs", Communication Research, Vol. 33 No. 5, pp. 370-90.

Creswell, J.W., Plano Clark, V.L., Gutmann, M.L. and Hanson, W.E. (2003), "Advanced mixed methods research designs", Handbook of mixed methods in social and behavioral research, pp. 209-40.

Davidson, E. (2006), "A technological frames perspective on information technology and organizational change", The Journal of Applied Behavioral Science, Vol. 42 No. 1, pp. 23-39.

Dawes, R.M. (1980), "Social Dilemmas", Annual Review of Psychology, Vol. 31 No. 1, pp. 169-93.

Deci, E.L. and Ryan, R.M. (2000), "The "What" and "Why" of Goal Pursuits: Human Needs and the Self-Determination of Behavior", Psychological Inquiry, Vol. 11 No. 4, pp. 227-68.

Fayard, A.-L. and Metiu, A. (2014), "The Role of Writing in Distributed Collaboration", Organization Science, Vol. 25 No. 5, pp. 1391-413.

Foss, N.J., Husted, K. and Michailova, S. (2010), "Governing Knowledge Sharing in Organizations: Levels of Analysis, Governance Mechanisms, and Research Directions", Journal of Management Studies, Vol. 47 No. 3, pp. 455-82.

Gefen, D., Karahanna, E. and Straub, D.W. (2003), "Trust and TAM in online shopping: An integrated model", Mis Quarterly, Vol. 27 No. 1, pp. 51-90.

Hargittai, E. and Walejko, G. (2008), "The participation divide: content creation and sharing in the digital age 1", Information, Community and Society, Vol. 11 No. 2, pp. 239-56. 
Hau, Y.S., Kim, B., Lee, H. and Kim, Y.-G. (2013), "The effects of individual motivations and social capital on employees' tacit and explicit knowledge sharing intentions", International Journal of Information Management, Vol. 33 No. 2, pp. 356-66.

Heisig, P. (2009), "Harmonisation of knowledge management-comparing $160 \mathrm{KM}$ frameworks around the globe", Journal of knowledge management, Vol. 13 No. 4, pp. 4-31.

Hofstede, G., Hofstede, G.J. and Minkov, M. (2010), Cultures and organizations: software of the mind: intercultural cooperation and its importance for survival, Third edition ed., McGraw-Hill.

Holsapple, C.W. and Joshi, K.D. (2000), "An investigation of factors that influence the management of knowledge in organizations", The Journal of Strategic Information Systems, Vol. 9 No. 2-3, pp. 235-61.

Hsu, M.-H., Ju, T.L., Yen, C.-H. and Chang, C.-M. (2007), "Knowledge sharing behavior in virtual communities: The relationship between trust, self-efficacy, and outcome expectations", International Journal of Human-Computer Studies, Vol. 65 No. 2, pp. 153-69.

Hung, S.-Y., Lai, H.-M. and Chang, W.-W. (2011), "Knowledge-sharing motivations affecting R\&D employees' acceptance of electronic knowledge repository", Behaviour \& Information Technology, Vol. 30 No. 2, pp. 213-30.

Jackson, S. (2011), "Organizational culture and information systems adoption: A three-perspective approach", Information and Organization, Vol. 21 No. 2, pp. 57-83.

Janz, B.D. and Prasarnphanich, P. (2003), "Understanding the Antecedents of Effective Knowledge Management: The Importance of a Knowledge-Centered Culture", Decision Sciences, Vol. 34 No. 2, pp. 351.

Jeon, S., Kim, Y.-G. and Koh, J. (2011), "An integrative model for knowledge sharing in communitiesof-practice", Journal of knowledge management, Vol. 15 No. 2, pp. 251-69.

King, W.R. and Marks, P.V. (2008), "Motivating knowledge sharing through a knowledge management system", Omega, Vol. 36 No. 1, pp. 131-46.

Kirchner, K., Razmerita, L. and Sudzina, F. (2008), "New Forms of Interaction and Knowledge Sharing on Web 2.0", in Miltiadis Lytras, E.D., Patricia Ordonez De Pablo (Ed.) Web2.0: The Business Model, Springer Science and Business Media, New York, NY, USA, pp. 21-37.

Kollock, P. (1998), "Social dilemmas: The anatomy of cooperation", Annual review of sociology, pp. 183-214.

Kuettner, T., Diehl, R. and Schubert, P. (2013), "Change factors in Enterprise 2.0 initiatives: Can we learn from ERP?", Electronic Markets, Vol. 23 No. 4, pp. 329-40. 
Lauring, J. (2009), "Managing cultural diversity and the process of knowledge sharing: A case from Denmark", Scandinavian Journal of Management, Vol. 25 No. 4, pp. 385-94.

Leonardi, P.M., Huysman, M. and Steinfield, C. (2013), "Enterprise Social Media: Definition, History, and Prospects for the Study of Social Technologies in Organizations", Journal of ComputerMediated Communication, Vol. 19 No. 1, pp. 1-19.

Leonardi, P.M. and Treem, J.W. (2012), "Knowledge management technology as a stage for strategic self-presentation: Implications for knowledge sharing in organizations", Information and Organization, Vol. 22 No. 1, pp. 37-59.

Lin, H.-F. (2007), "Effects of extrinsic and intrinsic motivation on employee knowledge sharing intentions", Journal of Information Science OnlineFirst, pp. 1-15.

Ma, W.W. and Chan, A. (2014), "Knowledge sharing and social media: Altruism, perceived online attachment motivation, and perceived online relationship commitment", Computers in Human Behavior, Vol. 39, pp. 51-58.

Majchrzak, A., Faraj, S., Kane, G.C. and Azad, B. (2013), "The Contradictory Influence of Social Media Affordances on Online Communal Knowledge Sharing", Journal of Computer Mediated Communication, Vol. 19 No. 1, pp. 38-55.

Matschke, C., Moskaliuk, J., Bokhorst, F., Schümmer, T. and Cress, U. (2014), "Motivational factors of information exchange in social information spaces", Computers in Human Behavior, Vol. 36 No. 0 , pp. 549-58.

Michailova, S. and Minbaeva, D.B. (2012), "Organizational values and knowledge sharing in multinational corporations: The Danisco case", International Business Review, Vol. 21 No. 1, pp. 59-70.

Mukamala, A. and Razmerita, L. (2014), "Which factors influence the Adoption of Social Software? An Exploratory Study of Indian Information Technology Consultancy Firms", Journal of Global Information Technology Management special issue: "IT in India and the Indian Region", Vol. 17 No. 3, pp. 188-212.

Newell, S., Robertson, M., Scarbrough, H. and Swan, J. (2009), Managing Knowledge Work and Innovation, Palgrave Macmillan, Hampshire, England.

Nonaka, I. (2007), "The Knowledge-Creating Company", Harvard Business Review, Vol. 85 No. 7/8, pp. $162-71$.

Paroutis, S. and Al Saleh, A. (2009), "Determinants of knowledge sharing using Web 2.0 technologies", Journal of knowledge management, Vol. 13 No. 4, pp. 52-63. 
Razmerita, L., Kirchner, K. and Nabeth, T. (2014), "Social Media In Organizations: Leveraging Personal And Collective Knowledge Processes", Journal of Organizational Computing and Electronic Commerce, Vol. 24 No. 1, pp. 74-93.

Razmerita, L., Kirchner, K. and Sudzina, F. (2009), "Personal Knowledge Management: The Role of Web 2.0 tools for managing knowledge at individual and organisational levels", Online Information Review, Vol. 33 No. 6, pp. 1021-39.

Razmerita, L., Phillips-Wren, G. and Jain, L. (2016), "Advances in Knowledge Management: An Overview", in Razmerita, L., Phillips-Wren, G. and Jain, L.C. (Eds.), Innovations in Knowledge Management, Springer Berlin Heidelberg, pp. 3-18.

Riege, A. (2007), "Actions to Overcome Knowledge Transfer Barriers in MNCs", Journal of knowledge management, Vol. 11 No. 1, pp. 48-67.

Roda, C., Angehrn, A., Nabeth, T. and Razmerita, L. (2003), "Using conversational agents to support the adoption of knowledge sharing practices", Interacting with Computers, Elsevier, Vol. 15 No. 1 , pp. 57-89.

Šajeva, S. (2007), "An Investigation of Critical Barriers to Effective Knowledge Management", Social Sciences/Socialiniai Mokslai, Vol. 58 No. 4, pp. 20-27.

Sandemose, A. (1953), "En flyktning krysser sitt spor. 1933", Reprint Oslo.

Teddlie, C. and Tashakkori, A. (2006), "A general typology of research designs featuring mixed methods", Research in the Schools, Vol. 13 No. 1, pp. 12-28.

Van Acker, F., Vermeulen, M., Kreijns, K., Lutgerink, J. and van Buuren, H. (2014), "The role of knowledge sharing self-efficacy in sharing Open Educational Resources", Computers in Human Behavior, Vol. 39, pp. 136-44.

Van den Hooff, B., Schouten, A.P. and Simonovski, S. (2012), "What one feels and what one knows: the influence of emotions on attitudes and intentions towards knowledge sharing", Journal of knowledge management, Vol. 16 No. 1, pp. 148-58.

Venkatesh, V., Brown, S.A. and Bala, H. (2013), "Bridging the Qualitative-Quantitative Divide: Guidelines for Conducting Mixed Methods Research in Information Systems", Mis Quarterly, Vol. 37 No. 1, pp. 21-54.

Von Krogh, G., Haefliger, S., Spaeth, S. and Wallin, M.W. (2012), "Carrots and rainbows: Motivation and social practice in open source software development", Mis Quarterly, Vol. 36 No. 2, pp. 649-76. 
Vuori, V. and Okkonen, J. (2012), "Knowledge sharing motivational factors of using an intraorganizational social media platform", Journal of knowledge management, Vol. 16 No. 4, pp. 592-603.

Wang, W.-T. and Hou, Y.-P. (2015), "Motivations of employees' knowledge sharing behaviors: A selfdetermination perspective", Information and Organization, Vol. 25 No. 1, pp. 1-26.

Wasko, M.M. and Faraj, S. (2005), "Why Should I Share? Examining Social Capital and Knowledge Contribution in Electronic Networks of Practice", Mis Quarterly, Vol. 29 No. 1, pp. 35-57.

Wilkesmann, U., Wilkesmann, M. and Virgillito, A. (2009), "The absence of cooperation is not necessarily defection: Structural and motivational constraints of knowledge transfer in a social dilemma situation", Organization Studies, Vol. 30 No. 10, pp. 1141-64.

Zhang, X., De Pablos, P.O. and Xu, Q. (2014), "Culture effects on the knowledge sharing in multinational virtual classes: A mixed method", Computers in Human Behavior, Vol. 31, pp. 491 98.

\section{Appendix}

Appendix 1: Questions from interviews with employees

\begin{tabular}{|c|c|}
\hline \multirow{8}{*}{ 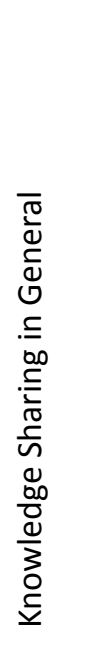 } & How often do you contribute and share your knowledge with colleagues? \\
\hline & How do you generally share knowledge internally in the organization? \\
\hline & What type of knowledge do you share most frequently? \\
\hline & What motivates you to contribute and share your knowledge? \\
\hline & Which of the following factors would prevent you from sharing your knowledge? \\
\hline & Is knowledge sharing actively encouraged in the organization? \\
\hline & How is knowledge sharing encouraged? \\
\hline & Is knowledge sharing recognized in the organization? \\
\hline \multirow{3}{*}{ 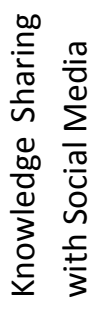 } & For which purposes do you use social media in your organization? \\
\hline & $\begin{array}{l}\text { How does knowledge sharing, specifically through the use of social media, } \\
\text { provide business value? }\end{array}$ \\
\hline & $\begin{array}{l}\text { What are the biggest issues you have experienced using social media for } \\
\text { knowledge sharing? }\end{array}$ \\
\hline
\end{tabular}




\begin{tabular}{|c|c|}
\hline \multirow{4}{*}{ 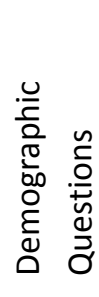 } & What is your position? \\
\hline & How many years have you worked in the organization? \\
\hline & What is your age? \\
\hline & What is your gender? \\
\hline
\end{tabular}

Appendix 2: Questions for interviews with managers

\begin{tabular}{|c|c|}
\hline \multirow{3}{*}{ 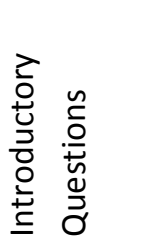 } & Industry Sector \\
\hline & Company Name \\
\hline & Social Media Platform \\
\hline \multirow{4}{*}{ 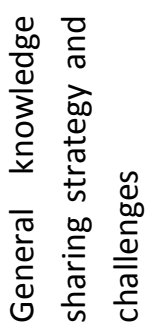 } & Does the organization have a clearly stated knowledge sharing strategy? \\
\hline & How do you track and measure the impact of knowledge sharing? \\
\hline & Have employee participation been a challenge? \\
\hline & What are the biggest challenges you have seen related to knowledge sharing? \\
\hline \multirow{2}{*}{ 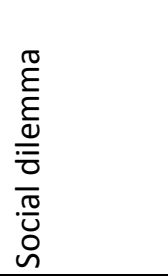 } & $\begin{array}{l}\text { Do managers actively motivate employees to share knowledge, in order to } \\
\text { prevent people from hoarding valuable knowledge? }\end{array}$ \\
\hline & $\begin{array}{l}\text { What is your take on the view that employees hoard knowledge in order to } \\
\text { stay valuable and decrease the risk of losing their job? }\end{array}$ \\
\hline \multirow{3}{*}{ 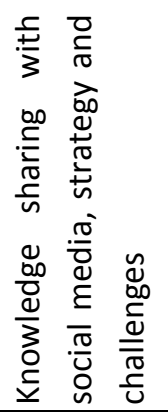 } & $\begin{array}{l}\text { What was the idea and goal behind implementing social media for internal } \\
\text { knowledge sharing? Has the project been successful? }\end{array}$ \\
\hline & $\begin{array}{l}\text { What are the main lessons learned from the use of social media for knowledge } \\
\text { sharing internally in the organization? }\end{array}$ \\
\hline & $\begin{array}{l}\text { What are the biggest challenges you have seen related to knowledge sharing } \\
\text { through social media? }\end{array}$ \\
\hline
\end{tabular}

